\title{
KISAH-KISAH DAN KEPERCAYAAN RAKYAT DI SEPUTAR KEPURBAKALAAN
}

\author{
Agus Aris Munandar
}

\begin{abstract}
Some archeological sites in Java, Bali, and Sumatra do not have historical data. This is because during the research, there has not been found any documents relating to the existence of the artifacts. The reconstruction of the relation between the sites and their history were made through analyzing the folk stories and local beliefs about the artifacts. Some of the artifacts are in the forms of temples, gates, water springs (source of holy water during the Hindu-Buddhist kingdoms in Java), stairs, caves for meditation, and layers of stones, such as found in Candi Bima (the Bima temple), Goa Jaran (the cave of the horse), and Bima Lukar water spring in Dieng; the story of the statue of Kunto Bimo in Borobudur temple; the story of Prince Gunadharma in the vicinity of the Borobudur temple, Moonstone in Kalasan temple, and the story of Prambanan temple and the palace of Ratu Baka in Jogjakarta, the Jalatunda water spring in Mojokerto; the story of the cave of Selamangleng and the story of the statue of Thothokkerot in Kediri; the Brahu temple and the Bajang Ratu gate in Trowulan; the first gate of Candi Sukuh in Karanganyar; the big Nekara in Pura Penataran Sasih in Gianyar, Bali; the Karang Kamulyan site in Ciamis, West Java; the Pasemah megalith, in Pagar Alam, South Sumatra. Van Peursen's ontological approach is used in the research to analyze the relation between the artifacts and the society, thus a study of the past is in the open.
\end{abstract}

\section{Keywords}

The study of the past, documentation, artifacts.

\begin{abstract}
Abstrak
Bangunan kepurbakalaan di beberapa tempat di Jawa, Bali dan Sumatra kehilangan kaitannya dengan sejarah. Hal ini disebabkan karena selama penelitian dilakukan tidak diketemukan dokumentasi mengenai keberadaan artifak tersebut. Rekonstruksi kaitan situs dengan sejarah kemudian dilakukan dengan meneliti cerita-cerita rakyat dan kepercayaan yang beredar di tengah-tengah penduduk di sekitarnya. Berbagai bentuk peninggalan berupa bangunan candi, pintu gerbang, petirtaan (sumber air suci masa Hindu-Budha), punden berundak, goa pertapaan, bahkan tumpukan batu alami seperti yang terdapat pada Candi Bima, Goa Jaran, dan Mata Air Bima Lukar di Dieng; Arca Kunto Bimo di Candi Borobudur, Pangeran Gunadharma di kompleks Candi Borobudur, Batu Bulan di Candi Kalasan, Percandian Prambanan dan Keraton Ratu Baka di Yogyakarta, Petirtaan Jalatunda di Mojokerto, Goa Selamangleng dan Arca Thothokkerot di Kediri; Candi Brahu dan Gapura Bajang Ratu di Trowulan; Gapura Satu Candi Sukuh di Karanganyar, Nekara Besar di Pura Penataran Sasih di Gianyar, Bali, Situs Karang Kamulyan di Ciamis, Jawa Barat; Megalitik Pasemah, Pagar Alam, Sumatra Selatan. Pendekatan ontologis Van Peursen dipakai dalam penelitian ini untuk melihat kaitan antara artifak dengan masyarakatnya dapat mengkaji kemasalaluan.
\end{abstract}

\section{Kata kunci}

Kepurbakalaan, dokumentasi, artefak. 


\section{PENGANTAR}

Di Tanah Jawa banyak dijumpai bangunan purbakala, seringkali bangunan, monumen, dan peninggalan lainnya, yang disebut dengan kepurbakalaan. Kepurbakalaan tidak hanya dijumpai di Pulau Jawa, tetapi juga terdapat di Sumatera, Bali, dan sedikit di Kalimantan, namun karena banyak data yang ditemukan di Jawa, telaah singkat ini membincangkan keadaan data di Jawa. Bentuk kepurbakalaan tersebut bermacam-macam, ada yang berupa bangunan candi, pintu gerbang, petirtaan (sumber air suci masa Hindu-Buddha), punden berundak, goa pertapaan, bahkan tumpukan batu alami yang mengandung nilai sejarah dan arkeologis dapat disebut dengan kepurbakalaan.

Dalam perjalanan masa, berbagai kepurbakalaan tersebut akhirnya dilupakan kaitan sejarahnya oleh penduduk yang sekarang tinggal di sekitarannya. Bisa jadi karena memang penduduk sekarang bukan lagi orang asli di wilayah itu melainkan para pendatang. Penduduk asli pendukung aktivitas di monumen tersebut-karena suatu sebab - telah pergi, dan wilayah tersebut yang semula kosong tidak berpenghuni, berada di lereng gunung, dalam hutan, atau di daerah yang sukar didatangi manusia. Dalam zaman selanjutnya, wilayah yang semula hutan itu telah dibuka dan akhirnya menjadi daerah hunian baru. Para pendatang ini kemudian menemukan kepurbakalaan yang tidak terurus, maka dikembangkanlah legenda baru untuk memahami bangunan kuno tersebut. Kisah rakyat atau kepercayaan setempat yang tumbuh sebagai respon terhadap adanya suatu kepurbakalaan di satu tempat merupakan upaya rakyat untuk menjelaskan kehadiran bangunan kuno di dekat kampung mereka. Kisah-kisah tersebut umumnya berkembang jauh di zaman kemudian, karena itu uraiannya kadangkala hanya penjelasan semampunya dari pengenalan penduduk kampung yang lugu. Bagi kajian kemasalaluan, misalnya disiplin sejarah dan arkeologi, kisah-kisah dan kepercayaan rakyat tentang suatu kepurbakalaan tetap dijadikan data, mungkin saja dapat membantu memecahkan permasalahan yang berkembang dalam penelitian.

\section{BEBERAPA KISAH DAN KEPERCAYAAN RAKYAT}

Uraian beberapa kisah dan kepercayaan rakyat yang berkaitan dengan suatu kepurbakalaan cukup menarik untuk disimak. Ada yang berupa pemaparan sebuah cerita dan ada pula yang berbentuk nilai atau konsep yang terus dipercaya oleh masyarakat setempat. Uraian beberapa kepercayaan dan kisah yang berhubungan dengan monumen purbakala itu antara lain sebagai berikut.

\section{CANDI BIMA}

Candi Bima, bernapaskan agama Hindu, terletak di dataran tinggi Dieng, Banjarnegara. Bangunan Candi Bima mempunyai gaya arsitektur gabungan antara 
bentuk atapnya yang menjulang tinggi gaya bangunan suci India utara, dan denahnya yang bujur sangkar dengan perbingkaian mendatar gaya India selatan (Suleiman 1981: 19). Penduduk percaya bahwa apabila seseorang berkeliling tujuh kali dimulai dari pintu masuk candi kemudian berakhir di pintu masuk itu juga dengan menganankan candi (searah jarum jam) disebut gerak pradaksina, maka keinginan yang diucapkan setelah berkeliling itu akan segera terkabul.

\section{GOA JARAN}

Goa alami terletak di dataran tinggi Dieng, di tepi Danau Telaga Warna. Goa ini mungkin berkaitan dengan ritus yang pernah terjadi di candi-candi Dieng pada masa silam, sebab sangat mungkin di Goa Jaran dan Goa Semar di sebelahnya digunakan sebagai pertapaan bagi kaum agamawan. Penduduk percaya bahwa para perempuan hendak melalui mulut goa tersebut, kedua tangannya harus disilangkan di depan dada, untuk melindungi bagian payudaranya. Jika tidak dilindungi, maka payudara mereka akan mengecil bahkan lenyap.

\section{TUK (MATA AIR) BIMA LUKAR}

Di tepian dataran tinggi Dieng, pada dinding tebing terdapat deretan Jaladwara (pancuran air dari batu berbentuk binatang mitos makara). Sekarang mata air tersebut telah disekat-sekat untuk ruang pria dan perempuan dan dibuat dinding dan atap, jadi tidak berupa pemandian asli lagi. Masyarakat percaya bahwa siapa yang mandi di pancuran air Tuk Bima Lukar, maka ia akan awet muda. Dewasa ini manfaat mandi di Tuk Bima Lukar semakin bermacam-macam lagi, membuat banyak orang datang untuk mandi dan bayar sejumlah uang kepada penjaganya.

\section{ARCA KUNTO BIMO DI CANDI BOROBUDUR}

Di tingkat Arupadhatu Candi Borobudur, terdapat satu stupa berlubang yang berisikan arca Dhyani Buddha Wairocana dengan sikap tangan Dharmmacakramudra (memutar roda dharma). Sikap tangan ini adalah menyatukan kedua tangan di depan dada, tangan kanan seperti menjumput di atas tangan kiri yang juga jemarinya menguncup di ujung. Pengunjung percaya bahwa siapa yang berhasil menyentuh pertemuan jemari kedua tangan arca Wairocana melalui lubang-lubang stupa, maka segala keinginan akan terkabulkan (Kempers \& Soekmono 1974: 43-44). Arca Wairocana itulah yang kemudian dinamakan dengan Kunto Bimo, walaupun penjelasan yang pasti tidak ada sampai hari ini. Mungkin sekali penduduk di masa silam yang tidak berpendidikan telah salah pengertian menganggap arca Dhyani Buddha itu dengan arca Bima, salah seorang Pandawa. 


\section{PANGERAN GUNADHARMA DAN CANDI BOROBUDUR}

Penduduk sekitar Candi Borobodur percaya bahwa arsitek pembangun candi itu bernama Gunadharma, salah seorang putra raja Mataram. Sekarang ia tidur abadi di selatan candi dalam bentuk rangkaian Pegunungan Menoreh (Manohara) mengawasi bangunan hasil rancangannya (Kempers \& Soekmono 1974: 42). Jika diperhatikan dengan seksama, rangkaian pegunungan Menoreh yang terletak di selatan Borobudur itu terlihat seperti orang tidur terlentang, terdapat bagian mahkota, kepala, dagu, leher (di arah timur) kemudian dada, dan bagian pegunungan yang agak meninggi mengesankan bagian perutnya yang membuncit, lalu lurus ke bagian kaki (arah barat pegunungan).

\section{BATU BULAN DI CANDI KALASAN}

Batu itu dibentuk seperti lengkungan busur, batu pipih, dan diletakkan di permukaan tanah di depan tangga arah timur Candi Kalasan yang bernapaskan agama Buddha Mahayana. Menurut prasastinya candi itu didirikan dalam tahun 700 Saka atau 778 M. Dalam pustaka arkeologi batu-batu demikian seringkali dinamakan moonstone atau batu bulan. Biasanya lazim dijumpai di bangunan suci Buddha di Sri Lanka (Ceylon), diletakkan di permukaan tanah juga, seperti halnya keset.

Di Sri Langka bentuk batu tersebut ada yang hampir seperti lingkaran penuh, setengah lingkaran, dan juga ada yang berbentuk seperti lengkung busur sebagaimana halnya yang dijumpai di Candi Kalasan, Jogjakarta. Penduduk di sekitarnya percaya bahwa jika seseorang sedang datang bulan, dilarang untuk berjalan memintas batu bulan Candi Kalasan, karena akan berakibat tidak baik bagi kesehatan perempuan itu.

\section{PERCANDIAN PRAMBANAN DAN KERATON RATU BAKA}

Dua kepurbakalaan, percandian Prambanan dan Keraton Ratu Baka dihubungkan dengan kisah rakyat Roro Mendut dan Raden Bandung Bandawasa. Kisah tersebut sudah sangat terkenal, ringkasnya putri Roro Mendut yang sering disebut mencintai ayahnya sendiri, Prabhu Ratu Boko. Maka ketika seorang ksatria bernama Raden Bandung Bandawasa melamar Roro Mendut, ia mengajukan syarat yang diperkirakannya tidak akan dipenuhi oleh Raden Bandung, yaitu meminta 1000 candi yang harus didirikan dalam satu malam.

Berkat kesaktian Raden Bandung dan juga dibantu oleh para lelembut (makhluk halus) di Tanah Jawa, pada tengah malam, candi-candi itu sudah hampir selesai dikerjakan. Roro Mendut yang menyaksikan kegiatan itu lalu meminta gadis-gadis di sekitar Prambanan untuk bangun dan menumbuk padi di lesung kayu, sehingga suaranya bertalu-talu bersahutan dan membuat ayam-ayam jantan berkokok, seperti halnya waktu fajar. Roro Mendut kemudian menemui Raden Bandung dan menyatakan bahwa sang 
ksatrya telah gagal memenuhi permintaannya, sebab malam telah mulai berakhir dan waktu fajar akan menjelang, tetapi pekerjaan Raden Bandung belum selesai. Penduduk Prambanan telah bangun dan menumbuk padi di lesung untuk mempersiapkan makanannya, dan ayam-ayam jantan telah berkokok pula, sebentar lagi matahari terbit, demikian ungkap Roro Mendut. Raden Bandung merasa kalah dan tidak mampu memenuhi syarat yang diajukan Roro Mendut. Ketika Roro Mendut kembali ke Istananya di Ratu Baka, keadaan kembali sepi, tidak ada suara tumbukan lesung dan kokok ayam jantan, ternyata malam masih larut, jauh dari dini hari. Maka Raden Bandung pun murka, Roro Mendut dikutuk menjadi arca batu, salah satu arca yang menjadi isi bilik candi Siwa Prambanan (arca Durga Mahisasuramardini). Kutukan pun dijatuhkan kepada gadis-gadis desa Prambanan, bahwa mereka akan sukar berjodoh dan banyak yang akan menjadi perawan tua karena telah membantu Roro Jonggrang. Prabhu Ratu Baka dapat dikalahkan oleh Raden Bandung, dan keratonnya berhasil dikuasainya.

Sekarang ini percandian Prambanan (dibangun dalam tahun $856 \mathrm{M}$, menurut prasasti Śiwagrha), Lumbung, dan Sewu adalah bukti bangunan candi-candi yang dahulu pernah diupayakan oleh Raden Bandung untuk memenuhi syarat Roro Jonggrang. Putri itu sekarang masih ada, abadi membeku menjadi batu di bilik utara Candi Śiwa dalam wujud arca Durga. Dalam pada itu gugusan pintu gerbang (berganda 3 dan 5), dinding benteng, batur-batur besar, petirtaan, goa pertapaan, dan jalanan kuno di kelompok Kepurbakalaan Ratu Baka adalah sisa istana Prabhu Ratu Baka ayahanda Roro Jonggrang.

Demikian kisah Roro Jonggrang-Raden Bandung dan hubungannya dengan berbagai kepurbakalaan di daerah Prambanan dan sekitarnya. Terdapat pula kepercayaan di kalangan remaja wilayah Prambanan yang sedang berpacaran untuk tidak berkunjung ke Prambanan, atau menaiki candi terbesar (Candi Śiwa) secara berdua bersamaan. Sebab jika dilakukan juga, maka hubungan asmara mereka akan putus dan tidak berlanjut, sebagaimana Roro Jonggrang dan Raden Bandung.

\section{PETIRTAAN JALATUNDA}

Pemandian kuno Jalatunda terletak di lereng barat Gunung Penanggungan, di dinding belakang petirtaan tersebut terdapat pahatan angka tahun 899 Śaka atau 977 Masehi. Selain itu, terdapat pula pahatan kata "gempeng" yang artinya hancur luluh lantak atau remuk. Jalatunda sangat mungkin dibangun ketika era pemerintahan raja Dharmmawangsa Tguh (991-1016 M). Penduduk desa-desa sekitar Penanggungan percaya kepada khasiat air yang selalu memancar dari jaladwara-jaladwara (pancuran air) Jalatunda. Di sudut utara dan selatan bagian dinding belakang petirtaan terdapat dua bilik dari balok-balok batu. Di bagian tengah menempel di dinding belakang bilik terdapat arca pancuran Naga (bilik selatan) dan arca pancuran berwujud Garuda (bilik utara). Namun sekarang kedua arca tersebut telah rusak terpenggal. 
Banyak penduduk dari daerah Mojokerto, Malang, Surabaya, dan wilayah Jawa Timur lainnya yang selalu datang untuk mandi di salah satu bilik kolam Jalatunda. Bilik Naga konon berkhasiat untuk menyegarkan ingatan, menentramkan hati, dan hal-hal lain yang berkenaan dengan kejiwaan. Akan tetapi sementara orang juga berpendapat bahwa jika terlalu sering mandi di bilik Naga, justru akan membuat orang mudah tergoncang jiwanya, tidak stabil dan ganti-ganti pemikiran, selayaknya ular berjalan yang meliuk-liuk tidak lurus. Khasiat air yang memancur di bilik Garuda adalah konon untuk kesuksesan duniawi. Mandi di bilik tersebut akan dapat naik pangkat, mudah mencapai cita-cita misalnya menjadi anggota DPRD, bupati, walikota, menjernihkan pikiran dalam belajar, dan akan sukses beruntung banyak bagi para pedagang, serta harapan positif lainnya.

\section{GOA SELAMANGLENG, KEDIRI}

Goa Selamangleng adalah goa buatan di tepi barat kota Kediri, di pegunungan Klothok. Goa tersebut sengaja dipahat membentuk ruang-ruang besar kecil, agaknya dipergunakan untuk keperluan meditasi para pertapa di masa silam. Kempers berpendapat bahwa Goa Selamangleng berasal dari akhir abad ke-10 M, karena terdapat kemiripan ornamen dengan Petirtaan Jalatunda yang berasal dari kurun waktu yang sama (Kempers 1959: 68).

Goa tersebut hingga sekarang sangat gelap, sebab tidak ada cahaya lain yang masuk ke dalamnya kecuali dari mulut goa. Terdapat arca berwujud relief tinggi yang menggambarkan tokoh pendeta yang sedang bertapa dengan sikap tangan tertentu. Berhubung goa tersebut terkesan angker, terdapat cerita rakyat yang menyatakan bahwa di goa tersebut bersemayam raja makhluk halus yang bernama Ki Buta Losaya. Makhluk itulah yang seringkali dihubungkan oleh para prewangan (medium/dukun) untuk menjelaskan permasalahan yang harus diatasi (Timoer 1981: 20 dan 24). Sampai sekarang kepercayaan tersebut masih dikenal dan masih ada orang dari tempat-tempat jauh biasanya bukan orang Kediri yang datang bertapa di Goa Selamangleng. Mereka membawa sajian bunga-bunga dan dupa, untuk kemudian tinggal selama beberapa hari di dalam goa. Sangatlah mungkin apabila setelah mendapat wangsit untuk menjawab permasalahan yang dihadapinya, atau niatnya yang sudah dikabulkan oleh kekuatan supranatural di goa tersebut, barulah orang itu kembali ke rumahnya.

Cerita rakyat lainnya menjelaskan bahwa Goa Selamangleng adalah tempat bertapanya Rara Sucian atau Dewi Kilisuci yang hidup tidak menikah. Ia adalah anak sulung dari Prabhu Resi Genthayu. Dewi Kilisuci juga mempunyai 4 orang adik lakilaki yang menjadi raja-raja. Tempat pertapaan Dewi Kilisuci sebenarnya di Gunung Pucangan, akan tetapi di waktu-waktu tertentu ia tinggal di Goa Selamangleng untuk bertapa juga, dan setelah beberapa waktu ia pun pindah lagi ke Pucangan. Mungkin cerita rakyat tersebut mengacaukan keterangan Goa Selamangleng, sebab goa buatan 
dengan nama Selamangleng memang ada dua tempat, pertama di Kediri dan kedua di Tulungagung, Kisah pertapaan Rara Sucian tersebut sangat mungkin berkenaan dengan Goa Selamangleng yang terdapat di selatan Tulungagung.

\section{ARCATHOTHOKKEROT}

Arca Thotokkerot sebenarnya adalah arca Dwarapala, penjaga bangunan suci yang terbuat dari batu monolit setinggi sekitar tiga meter. Ia digambarkan dengan sikap duduk bersila dengan satu kaki dilipat dengan dengkul menghadap ke atas. Biasanya Dwarapala terdiri dari dua arca yang diletakkan di tepi jalan masuk menuju ke halaman percandian atau bangunan suci lainnya. Akan tetapi yang ada sekarang hanyalah satu arca berwujud raksasa besar yang dinamakan oleh penduduk setempat dengan Thothokkerot. Arca itu berada di tepi sawah Desa Bulu Pasar, Kecamatan Pagu, Kabupaten Kediri. Arca itu sekarang sudah diangkat dan diletakkan di permukaan alas semen beton, awalnya tenggelam di tanah persawahan yang lembek.

Sudah sejak lama penduduk setempat mencoba "mengarang kisah sejarah" menurut versi mereka untuk menjelaskan kehadiran arca besar berwujud raksasa tersebut. Salah satu kisah sejarah yang dikenal adalah sebagai berikut.

Pada waktu Kerajaan Kadiri diperintah oleh raja Jayabhaya datanglah raksasa perempuan (raksasi) memasuki kota Daha, ia ingin menemui sang Raja dan ingin mengabdi sebagai istri raja. Akan tetapi penduduk Daha yang melihat kehadiran sosok raksasi itu menjadi ketakutan, apalagi mendengar keinginannya menjadi istri raja. Maka dikeroyoklah sang raksasi beramai-ramai oleh penduduk Daha.

Menjelang kematiannya, raksasi itu ditanya namanya, lalu raksasi itu menjawab ia bernama Nyai, dari hutan di daerah Lodoyong wilayah pantai selatan. Ketika Prabhu Jayabhaya tiba di tempat kejadian, ia terharu mendengar maksud kedatangan Buta (raksasi) Nyai. Sang Raja lalu memerintahkan kepada rakyatnya untuk membuat arca raksasi dan ditempatkan di desa tempat terjadinya peristiwa itu, lalu desa itu dinamakan Gumuruh, karena waktu terjadi pengeroyokan kepada raksasi itu terdengar suara gemuruh. Sampai sekarang arca Buta Nyai itu masih ada dinamakan dengan Thothokkerot.

Cerita rakyat lainnya menjelaskan perihal "sejarah arca Thothokkerot" sebagai berikut. Arca Thothokkerot tersebut adalah perwujudan dari Dewi Surengrana putri Raja Wurawan/Ngurawan. Dia sebenarnya tidak setuju apabila suaminya, yaitu Raden Panji Jayakusuma (Yudarawisrengga), putra raja Janggala kawin lagi. Walaupun putri yang akan dinikahinya itu adalah tunangan Raden Panji, bernama Dewi Sekartaji dari Kadiri. Raden Panji sebenarnya sudah menikah dengan Dewi Angreni, putri Patih Jenggala, Dewi Angreni kemudian dibunuh atas nasehat Dewi Kilisuci, kakak tertua para raja Janggala, Kadiri, Wurawan, dan Panaraga (Gelang-gelang), diharapkan setelah Angreni meninggal ia akan mau menikahi Sekartaji. 
Setelah kematian Angreni, Panji Jayakusuma minggat dari keraton, mengembara ke berbagai tempat akhirnya tiba di Wurawan. Rajanya bernama Lembupengarang adalah paman Panji, ia menerima Panji untuk bermukim di Wurawan untuk waktu yang lama, akhirnya ia dinikahkan dengan putri Wurawan yang bernama Surengrana, sebagaiman yang telah disebutkan terdahulu. Dalam pada itu Dewi Sekartaji tunangan Panji, selalu menjadi rebutan para raja untuk dijadikan permaisuri, antara lain Raja Klana-sewandana dari Hindustan. Walaupun Raja Klana-sewandana dan bala tentaranya berhasil dikalahkan oleh gabungan kekuatan Kadiri, Janggala, Wurawan, dan Panaraga, namun selanjutnya banyak raja lain di tanah Jawa untuk mencoba memperistri Sekar Taji, oleh karena itu kerapkali terjadi persaingan antara para raja yang menimbulkan kekacauan.

Satu-satunya jalan adalah Sekar Taji harus segera menikah dengan tunangannya yang sah, agar tidak menjadi rebutan para raja dan menimbulkan huru-hara. Kali ini pun yang tampil Dewi Kilisuci, ia diutus oleh para raja adik-adiknya untuk menemui Raja Wurawan mertua Raden Panji, raja Wurawan menyerahkan masalah itu kepada Panji, lalu Panji juga menjawab bahwa yang bisa menyetujui atau tidak adalah istrinya Dewi Surengrana. Maka Dewi Kili Suci bertemu berdua dengan Surengrana, setelah pembicaraan yang lama Dewi Surengrana menyetujuinya, sementara tafsiran apabila tidak setuju maka ia akan bernasib sama dengan Dewi Angreni, dibunuh, karena dianggap menghalangi cinta Panji. Walaupun setuju namun di hati kecilnya ia pasti tidak menerimanya, ia sangat benci kepada dewi Sekartaji madunya. Walaupun Sekartaji saudara sepupunya, namun dalam pandangan Surengrana ia merebut suaminya, maka jika bertemu dengan Dewi Sekartaji alias Candrakirana, Dewi Surengrana selalu bersungut-sungut (methothok) dan membunyikan giginya (bahasa Jawa: kerot-kerot) sebagai tanda kebencian dan permusuhannya. Karena perilakunya itu, maka ia dijuluki Thothokkerot. Setelah meninggal, Dewi Surengrana diwujudkan sebagai arca raksasa besar yang sampai sekarang masih ada dinamakan Thothokkerot.

Masih ada cerita rakyat lainnya yang berhubungan dengan arca Dwarapala besar Thothokkerot, seperti Thothokerot dengan Kudanarawangsa. Ada pula sarjana yang mencoba menghubungkan arca Thothokkerot dengan tokoh Calon Arang, atau juga ada tafsiran bahwa arca Thothokkerot tersebut menggambarkan penguasa perempuan yang selalu memberontak selama raja Airlangga memerintah (Timoer 1981), jadi tafsiran tentang arca itu masih belum memuaskan.

Hal yang jelas adalah bahwa segala cerita rakyat dan tafsiran para ahli itu cukup keliru, sebab selalu menyatakan bahwa Thothokerot sebagai raksasi (buta perempuan), padahal arca itu menggambarkan Dwarapala yang merupakan raksasa. Arca itu jelas Dwarapala sang raksasa penjaga bangunan suci, namun permasalahannya adalah sebagai Dwarapala harusnya ada dua arca, kemana arca satunya lagi?. Oleh karena hanya ada satu arca itulah kemudian muncul bermacam tafsiran. Anggapan umum bahwa Thothokkerot adalah raksasi disebabkan semua gigi taringnya telah dirusak 
orang, sehingga terkesan tersenyum seperti perempuan, bagian dada arca itu juga digambarkan besar, namun lazim dijumpai pada berbagai arca Dwarapala lainnya, jadi tetap menggambarkan raksasa. Jika benar menggambarkan raksasa tunggal, maka apakah arca itu masih dapat dianggap Dwarapala atau arca perwujudan? Biarkan masalah ini dijawab oleh para ahlinya di masa mendatang.

\section{CANDI BRAHU,TROWULAN}

Candi Brahu merupakan candi bata peninggalan zaman Majapahit, terletak di situs Trowulan, Desa Bejijong, Mojokerto. Ukuran denah dan kaki candi adalah 18 x 22,50 m, dengan tinggi candi hingga puncak atap yang tersisa sekarang adalah $20 \mathrm{~m}$. Sangat mungkin candi ini bernapaskan agama Buddha, karena pada salah satu sudut tingkatan atapnya masih dijumpai adanya bentuk lingkaran yang merupakan dasar dari stupa, dan stupa adalah lambang umum agama Buddha.

Kisah rakyat setempat menyatakan bahwa Candi Brahu berasal dari kata brawu, awu atau abu. Candi itu tempat abu atau tempat diperabukannya raja-raja Majapahit yang berjuluk Brawijaya, dari Brawijaya I hingga V jenazahnya dibakar di bangunan Candi Brahu tersebut. Bentuk candi memang berbeda apabila dibandingkan dengan candi-candi lainnya yang sezaman, di dinding luar tidak ada relung-relung untuk menempatkan arca, begitupun di bilik candi tidak ada batur atau pentas apapun untuk meletakkan arca. Bilik candi mempunyai langit-langit tinggi, sehingga terkesan seperti cerobong asap pembakaran, lantai bilik candi lebih rendah dari lantai pintu masuk. Sangat mungkin cerita penduduk tersebut ada benarnya, mengingat kondisi bangunan candi yang unik. Akan tetapi penelitian yang sistematis tentang adanya bangunan tempat pembakaran jenazah dalam masa Majapahit, belum pernah dilakukan, sehingga kesimpulan yang pasti belum diperoleh.

\section{GAPURA BAJANG RATU,TROWULAN}

Gapura Bajang Ratu merupakan gapura bata peninggalan Majapahit berbentuk gapura beratap menjulang tinggi seperti menara dengan tinggi $22 \mathrm{~m}$. Bentuk demikian di Bali dinamakan Kori Agung. Sekarang Gapura Bajang Ratu telah dipugar, dan di samping kanan-kiri gapura terdapat sambungan tembok yang sudah rusak menandakan gapura tersebut dahulu mempunyai tembok keliling yang melingkungi sesuatu bangunan penting. Hanya saja sampai sekarang belum diketahui bangunan apa yang dahulu dilengkapi dengan Gapura Bajang Ratu. Mengingat bentuk gapuranya yang tinggi besar dan sangat mengesankan secara arkeologis, maka dapat diasumsikan bahwa bangunan yang dahulu "dikawal" oleh gapura tersebut merupakan bangunan penting, hanya saja sekarang tidak tersisa lagi, mungkin dibuat dari bahan yang mudah lapuk.

Berkaitan dengan gapura Bajang Ratu terdapat kepercayaan yang sangat dipatuhi oleh mereka yang mengetahuinya. Kepercayaan itu mengungkapkan bahwa para 
pegawai negeri atau swasta, pejabat, dan orang yang berdudukan lainnya, terlarang untuk memintasi Gapura Bajang Ratu secara bolak-balik. Jika dilakukan juga maka orang itu akan sukar naik pangkat, memperoleh jabatan yang lebih baik, atau mendapat posisi yang lebih terhormat. Banyak pejabat daerah sekitar Trowulan begitu patuhnya kepada kepercayaan ini, daripada seumur hidup tidak naik pangkat, lebih baik melihat Bajang Ratu dari luarnya saja tidak perlu memasukinya.

\section{GAPURA I CANDI SUKUH}

Candi Sukuh terletak di Kabupaten Karanganyar, candi itu mempunyai halaman berteras tiga, bangunan candi berdiri di teras tertinggi paling belakang. Untuk memasuki tiap halaman dahulu orang harus melalui bangunan peralihan yang berupa gapura beratap. Sekarang gapura di halaman II dan III sudah runtuh, hanya tersisa bagian kaki bangunannya saja, mungkin dahulu bentuk pintu gerbang di halaman II dan III merupakan gapura beratap dan sama wujudnya dengan gapura halaman pertama.

Halaman pertama (paling rendah di sisi barat) masih mempunyai pintu gerbang, walaupun tidak lengkap lagi. Pintu itu menghadap ke barat, apabila seseorang memasuki pintu gerbang menuju Candi Sukuh, orang itu akan menghadap ke arah Gunung Lawu, sebab gugusan Candi Sukuh berada di lereng barat gunung tersebut. Pada lantai pintu gerbang terdapat bentuk relief tinggi yang menggambarkan kemaluan perempuan (yoni) dan kemaluan lelaki (lingga) yang sedang berhadapan seperti akan bertemu. Lingga digambarkan mempunyai empat benjolan berbentuk bulatan di bagian ujungnya.

Dahulu kerapkali relief Lingga-Yoni tersebut dijadikan media untuk menguji kesucian seorang gadis sebelum menikah. Gadis itu akan dibawa oleh calon suaminya ke gerbang I, lalu ia disuruh untuk meloncati relief Lingga-Yoni. Apabila kain yang dikenakannya robek, maka pertanda bahwa gadis itu tidak perawan lagi, sedangkan apabila meloncat kainnya tidak robek, maka ia masih suci. Kepercayaan ini masih berlaku hingga beberapa waktu yang lalu, namun sekarang berangsur-angsur ditinggalkan, walaupun masih ada satu dua orang yang mencobanya.

\section{NEKARA BESAR DI PURA PENATARAN SASIH}

Artefak yang berupa nekara (tambur perunggu) besar hingga sekarang masih disimpan di salah satu gedong di Pura Penataran Sasih, Pejeng, Gianyar, Bali. Tinggi nekara sekitar $2 \mathrm{~m}$, dan garis tengah bidang pukulnya hampir 1,6 m. Tubuh nekara dihias dengan motif deretan wajah manusia mirip topeng. Nekara dari Pejeng inilah yang sampai saat ini merupakan nekara terbesar yang terdapat di kepulauan Indonesia.

Cerita rakyat yang pertama berkenaan dengan nekara besar Pejeng menyatakan bahwa pada masa silam kereta Dewa Candra (bulan) ditarik sepuluh ekor kuda berkeliling dunia di atas awan. Ketika sampai di Bali, tepatnya di daerah Pejeng, salah satu roda kereta tersebut lepas dan jatuh ke bumi. Nekara besar yang sekarang 
disimpan di Pura Penataran Sasih itulah roda kereta milik Candra. Karena kesaktian Candra nekara besar tersebut kalau malam bersinar terang, seperti layaknya bulan. Maka penduduk dahulu menjulukinya juga dengan "Bulan Pejeng" , laporan-laporan peneliti asing pertama yang menelisik kebudayaan Bali, masih menyebut nekara Pejeng itu dengan "The moon of Pejeng". Pada suatu malam datang lah seorang pencuri yang akan melakukan kejahatannya di Pejeng, namun ia merasa terganggu oleh sinar terang yang dikeluarkan oleh nekara, ia khawatir kejahatannya mudah diketahui penduduk apabila nekara itu masih memendarkan sinarnya yang terang benderang. Lalu naiklah ia ke pohon, dari pohon tersebut ia mengencingi nekara, dengan segera sinar dari nekara meredup dan hilang. Si pencuri tewas karena uap panas dari nekara dan ia terjatuh dari pohon. Karena peristiwa itulah hingga sekarang nekara tersebut tidak pernah mengeluarkan sinarnya lagi, Demikian kisah rakyat Bali mengutarakannya.

\section{KEPURBAKALAAN KARANGKAMULYAN}

Kepurbakalaan Karang Kamulyan terletak di Desa Karangkamulyan, Kecamatan Cijeungjing, Ciamis, dengan luas sekitar 25 hektar. Selain sebagai situs purbakala, juga menjadi hutan lindung yang dijaga kelestariannya. Situs Karangkamulyan terletak di area pertemuan dua sungai, yaitu sungai Cimuntur dan Citanduy. Situs tersebut mempunyai beberapa macam kepurbakalaan, umumnya berupa lahan yang dipagar dengan tumpukan batu alami membentuk denah kurang lebih bujur sangkar. Di bagian tengah lahan berpagar terdapat objek sakral yang umumnya berupa menhir dari batu alami, batu lonjong pipih yang ditancapkan di permukaan tanah, dan di dekatnya tergeletak batu datar (dolmen atau batu persajian) atau tumpukan batu-batu kecil lainnya. Selain itu pernah dijumpai juga arca Ganesa dalam wujud kasar, Yoni yang telah terpenggal, dan juga batu fragmen bagian bangunan suatu punden atau candi yang telah rapuh.

Di area situs yang sama juga terdapat lahan datar. Hal yang menarik adalah tidak pernah ada rumput yang dapat tumbuh di lahan tersebut. Penduduk percaya tempat itu dahulu adalah arena untuk sabung ayam dalam Kisah Ciung Wanara. Selain itu terdapat juga mata air yang selalu mengeluarkan airnya, walau di musim kemarau sekalipun, dinamakan Cikahuripan, dahulu tempat mandi para putri raja kerajaan Galuh. Sama dengan sumber-sumber air lainnya di berbagai tempat, khasiat air Cikahuripan konon dapat membuat ketenangan jiwa, memudahkan rezeki, dan membuat orang awet muda.

Penduduk Ciamis percaya bahwa Situs Karang Kamulyan berhubungan dengan sejarah Kerajaan Galuh di masa silam. Kisah rakyat itu secara ringkas sebagai berikut. Pada masa silam di wilayah Ciamis berkembanglah Kerajaan Galuh, salah seorang rajanya ialah Prabhu Adimulya Permanadikusuma yang mempunyai dua orang istri, yaitu Dewi Naganingrum dan Dewi Pangrenyep. Pada suatu hari sang Prabhu ingin menarik diri dari dunia ramai, maka ia pun pergi ke hutan menjadi pertapa. Lama-kelamaan ia betah tinggal di hutan dan tidak mau memegang tampuk pemerintahan kerajaannya lagi, lalu 
menjadi seorang pertapa sakti yang sangat dikenal berjuluk Ajar Sukaresi.

Sepeninggal Raja Permanadikusuma, Kerajaan Galuh diperintah oleh raja baru yang semula adalah patih Galuh, bernama Jayadilaga. Ia kemudian menjadikan Dewi Naganingrum dan Pangrenyep sebagai istrinya. Pada suatu waktu terdengar oleh Jayadilaga bahwa ada seorang ajar yang sangat sakti dan tinggal di salah satu hutan wilayah Galuh. Jayadilaga merasa tersinggung dengan kepopuleran sang ajar yang bernama Sukaresi, lalu ia memerintahkan Dewi Naganingrum agar perutnya ditempel kuali dan dibalut dengan stagen, lalu oleh Jayadilaga dibawa ke tempat pertapaan Ajar Sukaresi, bertujuan untuk menguji kesaktian sang ajar.

Ringkas cerita bahwa ternyata Dewi Naganingrum menjadi hamil betulan, walaupun kualinya telah diambil. Bayi dalam kandungan diramal oleh Ajar Sukaresi adalah laki-laki yang akan merebut tahta Galuh dari Jayadilaga. Ketika Naganingrum melahirkan ternyata benar bayinya laki-laki, lalu diam-diam diambil oleh Dewi Pangrenyep untuk kemudian atas persetujuan Jayadilaga dibuang dalam peti kayu (kandaga) dan dihanyutkan di aliran Sungai Citanduy. Bayi itu kemudian diambil dan dibesarkan oleh Aki dan Nini Balangangtrang. Ketika mulai beranjak besar, anak tersebut diajak berburu ke hutan, saat itu ia melihat burung Ciung dan Wanara (kera), Aki Balangantrang kemudian memberi nama Ciung Wanara kepada anak asuhannya.

Raja di Galuh Prabhu Jayadilaga senang mengadu ayam jago, Ciung Wanara yang telah menjadi pemuda tampan pergi ke Galuh hendak mengadu ayam jagonya dengan ayam jago milik raja. Taruhannya jika Ciung Wanara kalah ia harus pergi jauh-jauh dari wilayah Galuh, tetapi jika ayam Ciung Wanara menang, raja akan memberikan setengah wilayah Galuh kepada Ciung Wanara. Ternyata ayam jago Raja Jayadilaga kalah, namun sang raja ingkar janji tidak mau memberikan setengah wilayah Galuh kepada Ciung Wanara. Sebagai niat baik raja, Ciung Wanara boleh mengabdi di kedaton Galuh, karena Ciung Wanara dikenal sebagai pandai besi yang mahir.

Jayadilaga dengan Dewi Pangrenyep mempunyai anak lelaki yang bernama Hariang Banga. Ia telah tumbuh menjadi pemuda yang gagah dan sakti, sebaya dengan Ciung Wanara. Pada suatu hari Ciung Wanara membuat kerangkeng dari besi yang cukup indah, lalu ia meminta raja Jayadilaga dan permaisurinya untuk melihat-lihat hiasan dalam kerangkeng tersebut. Setelah mereka berdua masuk dalam kerangkeng, sekejap kemudian Ciung Wanara menguncinya dari luar sehingga mereka terpenjara. Ciung Wanara kemudian menduduki tahta Galuh menjadi penguasa kerajaan warisan raja Permanadikusuma.

Mendengar ayah dan ibunya dipenjara dalam kerangkeng besi Hariang Banga datang dan hendak membebaskan mereka, namun tentu saja harus berhadapan dengan Ciung Wanara. Perkelahian pun tiada dihindarkan lagi, mereka sama-sama muda, sakti, dan kuat. Adu kesaktian itu berlangsung lama, konon sampai berhari-hari tidak ada yang akan kalah atau menang. Menyaksikan hal itu para kokolot negeri (pendeta, rsi, 
purohita, dan kaum agamawan lain) memisahkan mereka berdua, lalu mereka harus membagi dua kerajaan Galuh. Maka diputuskanlah bahwa Galuh dibagi dua, dengan pembatas Sungai Citanduy. Sebelah timur sungai bagian Hariang Banga dan sebelah baratnya diperintah oleh Ciung Wanara. Mereka memerintah di wilayah masing-masing dan kisah pun berakhir (Sukardja 1997: 28-29).

Kepurbakalaan Karangkamulyan banyak yang dihubungkan dengan bagianbagian dari cerita Ciung Wanara. Misalnya situs Batu Pangcalikan dipercaya dahulu sebagai tempat duduknya raja-raja Galuh, di tempat itu masih banyak orang datang bertapa untuk meminta petunjuk dari kekuatan gaib. Kemudian lahan datar yang tidak ditumbuhi rumput, dipercaya sebagai arena sabung ayam antara ayam jago raja Jayadilaga dan ayam jagonya Ciung Wanara. Kemudian terdapat Batu Panyandaan yang sebenarnya menhir dan batu datar, dipercaya sebagai tempat Dewi Naganingrum duduk bersandar ketika melahirkan Ciung Wanara. Kemudian ada petirtaan Cikahuripan sebagai tempat para putri dan penghuni istana Galuh mandi dan membersihkan badan, dan situs-situs lainnya juga berhubungan dengan sejarah Galuh. Diterangkan dalam kisah itu bahwa ibu kota Galuh semula bernama Medang Kamulyan, kemudian diganti nama menjadi Karangkamulyan, maka situs itu bekas ibu kota kerajaan Galuh.

\section{MEGALITIK PASEMAH}

Di wilayah inti orang Pasemah (Besemah) bermukim, yaitu di Pagar Alam, Sumatra Selatan, banyak dijumpai peninggalan megalitik dengan bermacam bentuknya. Ada yang menggambarkan orang naik gajah, orang naik kerbau, orang sedang duduk bersila satu kaki dilipat ke atas, menhir-menhir, orang sedang berkelahi dengan ular, meja-meja batu, bilik batu dan lainnya lagi. Megalitik tersebut tersebar di wilayah dataran tinggi, perkebunan, dan di lereng-lereng Gunung Dempo (3159 m).

Seorang ahli Belanda yang bernama A. N. J. Th. a. Th. van Van Der Hoop menyatakan bahwa para pendukung kebudayaan megalitik di Pasemah bukan orangorang Negrito, sebagaimana yang pernah dinyatakan oleh L. C. Westenenk (1921 \& 1922), melainkan orang-orang setempat sendiri. Merekalah nenek moyang etnik Melayu yang berkembang di masa kemudian. Masa itu di wilayah Pasemah berkembang kebudayaan megalitik bersamaan dengan teknik pembuatan benda-benda perunggu, hal itulah yang terlihat dari temuan kekunaan yang ada di wilayah tersebut (1932: 156-157). Kebudayaan tersebut berkembang pada sekitar abad-abad terakhir sebelum Masehi hingga abad-abad pertama tarikh Masehi. Masa ini dalam perkembangan sejarah kebudayaan dinamakan dengan Proto-Sejarah, yaitu masa peralihan antara era prasejarah ke zaman sejarah.

Itu semua adalah penjelasan ilmiah yang dibentangkan oleh para pakar kebudayaan masa silam di wilayah Sumatra Selatan, akan tetapi penduduk setempat mempunyai pengetahuannya sendiri untuk menjelaskan berbagai fenomena megalitik 
yang banyak dijumpai berserakan di lereng Gunung Dempo. Penduduk percaya bahwa bentuk batu-batu dengan berbagai figur manusia dan hewan itu adalah akibat perbuatan seorang sakti yang bernama Si Pahit Lidah. Pada masa silam hiduplah di wilayah sekitar Gunung Dempo seorang yang lidahnya bertuah, jika ia meludah dan mengenai hewan atau manusia, maka hewan dan manusia itu segera menjadi batu. Begitupun jika ia menjilat apapun dengan kesaktiannya maka benda-benda itu akan berubah menjadi batu, oleh karena itu ia dijuluki si Pahit Lidah.

Di wilayah yang sama hidup orang sakti lainnya, ia bernama si Mata Empat, karena ada tambahan dua mata lainnya di bagian belakang kepala yang selalu ditutupi rambutnya yang panjang. Si Mata Empat mendengar bahwa ada orang yang begitu saktinya bernama Pahit Lidah, karena akibat air liurnya saja orang bisa jadi batu, ia penasaran ingin mengadu kesaktian dengan Pahit Lidah.

Dalam suatu kesempatan keduanya bertemu, lalu si Mata Empat mengajukan tantangan bahwa siapa yang mampu menghindari batu yang dijatuhkan dari atas pohon, sedangkan ia tidur tertelungkup maka ia adalah pemenangnya. Pahit Lidah menyetujuinya, giliran pertama yang tidur tertelungkup di bawah pohon adalah Mata Empat, si Pahit Lidah naik ke pohon sambil membawa batu besar untuk dijatuhkan kepada Mata Empat.

Sudah barang tentu Mata Empat mampu menghindari batu yang dijatuhkan ke arahnya, karena ia mempunyai dua mata lainnya di bagian belakang kepala. Jadi walaupun ia tertelungkup namun masih dapat melihat jatuhnya batu, ia segera berguling menghindari. Lalu menyusul si Pahit Lidah yang tertelungkup di bawah pohon, dan Mata Empat menjatuhinya dengan batu. Pahit Lidah tidak mampu menghindar, ia terkena batu besar dan langsung tewas. Si Mata Empat senang sekali dan ia tertawatawa dan menyatakan bahwa di wilayah itu dan sekitarnya dia adalah manusia yang paling sakti. Akan tetapi ia merasa penasaran terhadap kehebatan air liur si Pahit Lidah, kemudian jenazah si Pahit Lidah dibalikkan, dan mulutnya disentuhnya dengan tangannya. Tangan si Mata Empat terkena air liur yang ada di mulut Pahit Lidah, berubahlah ia seketika menjadi arca batu, terkena kesaktian si Pahit Lidah.

Tabel 1

Hubungan Kisah dan Kepercayaan Rakyat dengan Kepurbakalaan

\begin{tabular}{|l|c|c|c|c|l|}
\hline $\begin{array}{c}\text { NAMA } \\
\text { KEPURBKALAAN }\end{array}$ & $\begin{array}{c}\text { KISAH } \\
\text { RAKYAT }\end{array}$ & $\begin{array}{c}\text { KEPER- } \\
\text { CAYAAN }\end{array}$ & $\begin{array}{c}\text { DAMPAK } \\
\text { POSITIF }\end{array}$ & $\begin{array}{c}\text { DAMPAK } \\
\text { NEGATIF }\end{array}$ & \multicolumn{1}{|c|}{ KETERANGAN } \\
\hline Candi Bima, Dieng & - & $\sqrt{ }$ & $\sqrt{ }$ & - & $\begin{array}{l}\text { Berkeliling candi dan mengajukan } \\
\text { permohonan. }\end{array}$ \\
\hline Goa Jaran, Dieng & - & $\sqrt{ }$ & - & $\begin{array}{l}\text { Harus menutup dada bagi } \\
\text { perempuan. }\end{array}$ \\
\hline Tuk Bima Lukar & - & $\sqrt{ }$ & $\sqrt{ }$ & - & Mandi di mata air kuno \\
\hline $\begin{array}{l}\text { Arca Kunto Bimo di } \\
\text { Candi Borobudur }\end{array}$ & - & $\sqrt{ }$ & $\sqrt{ }$ & - & $\begin{array}{l}\text { Harus menyentuh ujung tangan } \\
\text { arca Buddha }\end{array}$ \\
\hline $\begin{array}{l}\text { Gunadharma di } \\
\text { Pegunungan Menoreh }\end{array}$ & $\sqrt{ }$ & - & $\sqrt{ }$ & - & $\begin{array}{l}\text { Pegunungan Menoreh yang } \\
\text { menyerupai orang terlentang }\end{array}$ \\
\hline
\end{tabular}


Kisah-kisah dan Kepercayaan Rakyat di Seputar Kepurbakalaan, Agus Aris M. 15

\begin{tabular}{|c|c|c|c|c|c|}
\hline $\begin{array}{c}\text { NAMA } \\
\text { KEPURBAKALAAN }\end{array}$ & $\begin{array}{l}\text { KISAH } \\
\text { RAKYAT }\end{array}$ & $\begin{array}{l}\text { KEPER- } \\
\text { CAYAAN }\end{array}$ & $\begin{array}{l}\text { DAMPAK } \\
\text { POSITIF }\end{array}$ & $\begin{array}{l}\text { DAMPAK } \\
\text { NEGATIF }\end{array}$ & KETERANGAN \\
\hline $\begin{array}{l}\text { Batu Bulan di Candi } \\
\text { Kalasan }\end{array}$ & - & $\sqrt{ }$ & - & $\sqrt{ }$ & $\begin{array}{l}\text { Wanita datang bulan dilarang } \\
\text { melalui batu bulan }\end{array}$ \\
\hline $\begin{array}{l}\text { Prambanan dan Ratu } \\
\text { Baka }\end{array}$ & $\sqrt{ }$ & $\sqrt{ }$ & - & $\sqrt{ }$ & $\begin{array}{l}\text { Terlarang bagi sepasang kekasih } \\
\text { untuk ke Prambanan, cinta mereka } \\
\text { akan berakhir }\end{array}$ \\
\hline Petirtaan Jalatunda & - & $\sqrt{ }$ & $\sqrt{ }$ & $\sqrt{ }$ & $\begin{array}{l}\text { Terdapat dua bilik petirtaan } \\
\text { dengan arca pancuran Naga dan } \\
\text { Garuda. }\end{array}$ \\
\hline $\begin{array}{l}\text { Goa Selamangleng, } \\
\text { Kediri }\end{array}$ & $\sqrt{ }$ & - & $?$ & $?$ & $\begin{array}{l}\text { Tidak berkaitan langsung dengan } \\
\text { masyarakat sekarang }\end{array}$ \\
\hline $\begin{array}{l}\text { Arca Thothokkerot, } \\
\text { Kediri }\end{array}$ & $\sqrt{ }$ & - & ? & $?$ & Arca Dwarapala tunggal, monolit. \\
\hline $\begin{array}{l}\text { Candi Brahu, } \\
\text { Trowulan }\end{array}$ & $\sqrt{ }$ & - & $?$ & $?$ & $\begin{array}{l}\text { Tidak berkaitan langsung dengan } \\
\text { masyarakat sekarang }\end{array}$ \\
\hline $\begin{array}{l}\text { Gapura Bajang Ratu, } \\
\text { Trowulan }\end{array}$ & - & $\sqrt{ }$ & - & $\sqrt{ }$ & $\begin{array}{l}\text { Terlarang berjalan bolak-balik } \\
\text { memintas gapura. }\end{array}$ \\
\hline $\begin{array}{l}\text { Gapura I, Candi } \\
\text { Sukuh, Karanganyar }\end{array}$ & - & $\sqrt{ }$ & - & $\sqrt{ }$ & Pengujian kesucian seorang gadis \\
\hline $\begin{array}{l}\text { Kepurbakalaan Karang } \\
\text { Kamulyan, Ciamis }\end{array}$ & $\sqrt{ }$ & $\sqrt{ }$ & $\sqrt{ }$ & - & $\begin{array}{l}\text { Kumpulan bermacam } \\
\text { kepurbakalan tradisi megalitik }\end{array}$ \\
\hline $\begin{array}{l}\text { Nekara besar di Pura } \\
\text { Penataran Sasih, } \\
\text { Gianyar }\end{array}$ & $\sqrt{ }$ & - & $?$ & $?$ & $\begin{array}{l}\text { Nekara besar yang disebut juga } \\
\text { "The moon of Pejeng" }\end{array}$ \\
\hline $\begin{array}{l}\text { Megalitik Pasemah, } \\
\text { Pagar Alam, Sumsel. }\end{array}$ & $\sqrt{ }$ & - & $?$ & $?$ & $\begin{array}{l}\text { Sebaran megalitik di area luas } \\
\text { yang menggambarkan bermacam } \\
\text { bentuk dan wujud. }\end{array}$ \\
\hline
\end{tabular}

\section{UPAYA PENJELASAN ONTOLOGIS}

Pada suatu ketika dalam perkembangan kebudayaannya manusia mulai melepaskan dirinya dari pemikiran yang serba mitos. Semula mereka sangat dikungkung oleh ketidaktahuannya, dan mengagumi serta takut kepada berbagai fenomena yang ada di sekitar kehidupannya dan menggetarkan nuraninya. Perkembangan kebudayaan itu menurut Van Peursen (1976) disebut dengan alam pikiran mitis. Ketika manusia telah mulai mencoba memahami alam sekitarnya dengan memberikan uraian kisah atau memberi nama kepada gejala alam yang menakutkan, menciptakan alur pemikiran yang berkenaan dengan suatu fenomena sehingga dapat diterima secara khalayak, atau upaya lainnya, maka kebudayaan manusia mengembangkan alam pikiran Ontologis.

Dalam tahapan ini manusia sebagai subjek telah menarik diri ke luar dari keterikatan kepada alam sekitar sebagai objek, manusia memandang alam sebagai sesuatu yang lain yang berada di luar dirinya. Alam pemikiran dalam kebudayaan yang berikut disebut Fungsionil, ketika manusia dapat memanfaatkan alam sebaik-baiknya untuk keperluan dan kemudahan hidupnya, lingkungan alam juga dapat berkembang atau lestari berkat campur manusia. Terjadi "dialog" antara manusia dan alam sehingga dapat saling memanfaatkan berkembang bersama secara harmonis (Van Peursen 1976: 34-117).

Telah dapat dipastikan bahwa terjadinya berbagai kisah rakyat dan kepercayaan 
rakyat tersebut muncul di masa belakangan, lebih kemudian dari peristiwa sejarah tertentu pada saat masih berfungsinya suatu kepurbakalaan. Sebut saja suatu contoh lain, bahwa di dinding ruang penampil (lorong pintu masuk ke bagian bilik) di Candi Mendut, digambarkan relief Yaksa Atawaka dan Yaksi Hariti yang sedang bermainmain dengan banyak anak kecil. Dalam mitos Buddha yaksa dan yaksi tersebut memang dekat dengan anak kecil, karena ditugaskan oleh Buddha untuk mengasuh anak-anak kecil dalam bimbingan dharma Buddha. Semula mereka adalah raksasa yang gemar membunuh dan memakan anak-anak, namun setelah diberi wejangan dharma oleh Buddha, kedua yaksa itu sadar dan diperintahkan oleh Buddha menjadi pengasuh rohani anak-anak. Itulah mitos sebenarnya dari Atawaka dan Hariti.

Akan tetapi dalam perkembangan selanjutnya, terdapat sementara orang Jawa yang tinggal di sekitar Candi Mendut memahami relief Atawaka dan Hariti itu dengan pengertian lain, suatu kepercayaan rakyat yang berkembang kemudian. Apabila terdapat pasangan yang telah kawin namun belum juga dikaruniai anak, maka pasangan itu harus bermeditasi dan datang mengadu kepada Atawaka (si suami) dan ke Hariti (si istri) untuk memohon diberkati agar segera mendapat keturunan. Dalam relief memang nyata terlihat bahwa yaksa/yaksi itu dikerumuni anak-anak, bermain dengan anak-anak, sehingga "tafsir baru" yang mengemuka adalah mereka dewa-dewi penolong orang yang ingin mempunyai anak keturunan.

Hal itulah yang mungkin dapat dipandang sebagai pembentukan mitos atau kepercayaan baru oleh masyarakat masa kini untuk menjelaskan suatu fenomena budaya yang menarik perhatian mereka. Penceritaan lisan tentang fenomena budaya di luar konteks sejarah kebudayaan yang sebenarnya merupakan contoh dari alam pemikiran ontologis dalam kebudayaan (Van Peursen 1976: 59-84). Ketika manusia berusaha untuk menarik diri keluar dari ketidaktahuannya terhadap objek (yaksalyaksi) dan memberikan penjelasan yang sesuai dengan kognisi mereka sendiri yang disesuaikan dengan keadaan zaman.

Bagan 1

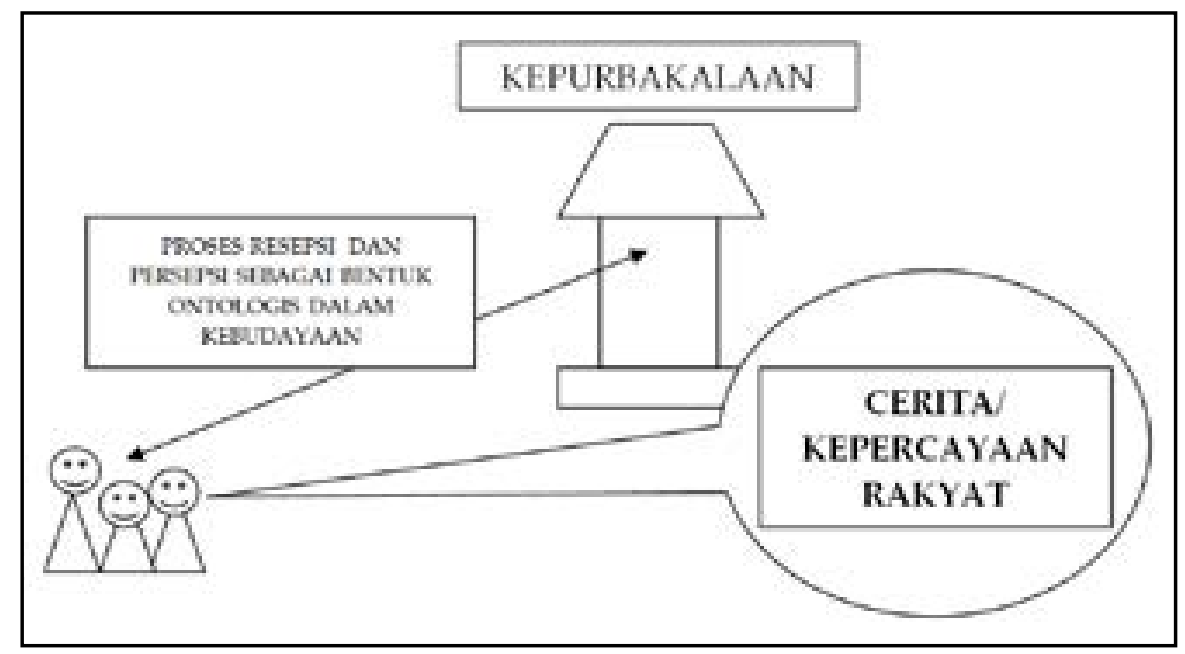


Bagan 1 mengungkapkan secara sederhana terbentuknya cerita-cerita dan kepercayaan rakyat, penduduk sekitar kepurbakalaan menyaksikan dahulu adanya kepurbakalaan, kemudian barulah dipahami dengan cerita/kepercayaan rakyat.

Pembentukan kepercayaan rakyat yang baru terhadap suatu kepurbakalaan dapat terjadi di masa yang sangat kemudian. Ternyata kepercayaan baru itu memang sengaja direkayasa karena ada yang membawa keuntungan komersial bagi kalangan tertentu, contoh yang banyak terjadi di seputar kepurbakalaan Islam di Jawa. Di lingkungan kompleks makam Sunan Gunung Jati, di bukit Gunung Sembung, Cirebon, terdapat kepercayaan baru di kalangan para penziarah. Para penziarah "diwajibkan" untuk mengambil air wudlu terlebih dahulu sebelum memasuki kompleks. Air wudlu tersebut dalam tempayan-tempayan kuno yang air nya harus diisi ulang oleh kelompok juru kunci. Untuk mengambil wudlu itu dikenai uang sukarela sebagai sedekah yang jumlahnya telah ditentukan oleh kelompok juru kunci. Bukankah itu suatu kepercayaan yang direkayasa? Sebab mengambil air wudlu hanya diwajibkan untuk sholat, bukan untuk masuk ziarah ke kompleks makam, terasa terlalu dilebih-lebihkan, karena ada jumlah uang yang cukup banyak masuk ke kotak sedekah untuk para juru kunci.

Cerita rakyat yang dipercaya oleh penduduk sekitar kepurbakalaan, sejatinya merupakan suatu tradisi kelisanan yang bersifat kerakyatan. Menurut William Bascom (1965) folklore dalam bentuk prosa terdiri dari tiga bentuk, yaitu (1) mitos, (2) legenda, dan (3) dongeng. Masing-masingnya mempunyai ciri sendiri-sendiri, dalam kisah yang berbentuk mitos, (a) tokoh-tokoh dianggap bukan manusia, melainkan para dewa, atau makhluk setengah dewa, (b) sifat cerita suci, dan dipercaya sebagai peristiwa yang pernah terjadi, (c) tempat kejadian atau setting cerita di dunia lain, dunia dewa-dewa, kahyangan atau di dunia manusia pada masa yang paling awalnya, (d) waktu terjadinya kisah tersebut berada dalam zaman yang sangat kuno, ketika manusia belum ada, atau ketika manusia belum banyak hidup di muka bumi. Legenda mempunyai ciri, (a) tokoh-tokoh cerita adalah manusia, (b) sifat cerita sekuler, ada juga ada yang suci dan dipercaya pernah terjadi di masa silam, (c) setting di dunia manusia, (d) waktu terjadi masa silam yang tidak terlalu jauh. Adapun ciri dongeng adalah (a) tokoh-tokoh cerita manusia, hewan, atau makhluk rekaan, (b) sifat cerita sekuler, dan uraian cerita hanya karangan saja, (c) tempat terjadinya cerita dapat dimana saja, (d) waktu terjadinya dapat kapan saja, di masa silam, masa kini, bahkan masa yang akan datang (Bascom 1965, Sutarto 1997: 14).

Apabila menilik ciri kisah dalam bentuk prosa yang dihubungkan dengan suatu kepurbakalaan, maka dapat dinyatakan bahwa cerita-cerita rakyat yang berhubungan dengan kepurbakalaan, candi, arca, goa dan lain-lain dapat digolongkan sebagai kisah legenda, menurut klasifikasi William Bascom. Artinya tokoh cerita adalah manusia, misalnya Dewi Surengrana, Rara Jonggrang, Raden Bandung, Ciung Wanara, si Pahit Lidah, dan sebagainya. Sifat cerita tidak dipandang sakral, hanya semata-mata cerita 
yang dapat dituturkan tidak terikat pada aturan keagamaan. Ada juga kisah legenda yang bersifat sakral dan angker misalnya kisah perkawinan antara Pangeran Senapati dengan Ratu Kidul. Cerita-cerita si Pahit Lidah dan Mata Empat, Ciung Wanara-Hariang Banga, Pangeran Gunadharma, dan Thothokkerot dipercaya pernah terjadi di masa silam yang tidak terlalu jauh dari masa sekarang. Begitupun waktu terjadinya bukan pada zaman kuno sekali, melainkan zaman yang masih bersinambung dengan masa kini.

Dalam pada itu kepercayaan rakyat terhadap mujizat yang dimiliki kepurbakalaan dapat diterangkan sebagai kesinambungan tradisi dari masa prasejarah. Dalam masa prasejarah bahkan hingga zaman sekarang masih terdapat konsep fetisisme. Konsep itu berasal dari kata fetis yang artinya jimat, adalah kepercayaan yang sangat berlebihan kepada benda mati, hewan, pohonan, benda buatan ataupun alami. Kepercayaan itu didasarkan bahwa benda-benda tersebut mempunyai kekuatan gaib yang dapat membantu permasalahan manusia.

Dengan demikian walaupun kepercayaan itu berhubungan dengan agama tertentu, tetap saja dinyatakan bahwa orang-orang yang mempercayai kekuatan yang dimiliki oleh suatu kepurbakalaan masih menganut paham fetisisme, walau mereka tidak memahami lagi. Fetisisme sejatinya adalah kepercayaan asli penduduk kepulauan Nusantara sebelum masuknya pengaruh asing (India, Cina, Islam, Kolonial Belanda). Sampai sekarang di banyak suku bangsa Nusantara fetisisme tetap berkembang, ada yang percaya kepada bermacam benda sebagai jimat, batu besar, pohon besar, anak panah, keris, selembar kain, gamelan, dan banyak lainnya. Fetisisme awalnya terjadi secara tidak sengaja dan kekuatan benda itu semula hanya dirasakan oleh seseorang saja, namun kemudian berdasarkan cerita dari mulut ke mulut, kesaktian benda menjadi menyebar luas di masyarakat, mengakibatkan banyak orang yang percaya. Mulailah kepercayaan itu berkembang dan akhirnya diwariskan dari satu generasi ke generasi berikutnya.

Mengenai kepercayaan yang baru dikembangkan oleh orang-orang tertentu, agaknya lebih didasarkan kepada keuntungan ekonomi semata. Hal yang memprihatinkan adalah justru legenda yang direkayasa atau kepercayaan yang baru dikarang tersebut lalu dipercaya orang-orang. Banyak anggota masyarakat yang percaya sepenuh hati terhadap kepercayaan baru, dengan alasan yang berbeda mereka tidak segan untuk memberikan sedekah kepada para pengurus tempat keramat, kuburan, kabuyutan, dan lain-lain. Tidak hanya kepada benda-benda atau tempat-tempat yang mengandung nilai tradisi, namun dapat juga terjadi pada benda-benda modern dan tempat-tempat yang baru dikenal dalam waktu belakangan ini, inilah yang dapat disebut sebagai fetisisme kontemporer (Contemporary Fetisism).

Demikianlah bahwa dalam masyarakat Indonesia sekarang ini sebenarnya masih banyak fenomena budaya yang mempunyai akar sejak masa silam. Banyak pula tradisi dan kepercayaan baru yang diciptakan, namun tanpa sadar sejatinya hanya mengubah "baju"nya saja, sebab isinya tetap sama. Semua kisah dan kepercayaan rakyat yang 
bersifat tradisi atau yang merupakan gubahan baru, dapat disebut berada dalam tahap ontologis dalam kebudayaan. Maka dari itu dapat kiranya dinyatakan bahwa sebagian besar masyarakat Indonesia masih hidup dalam suasana ontologis, bahkan ada pula yang masih dilingkupi oleh suasana mitis.

\section{EPILOG}

Beberapa catatan tentang cerita rakyat yang dituturkan secara lisan berkenaan dengan kepurbakalaan cukup banyak, antara lain sebagai berikut.

1. Cerita-cerita rakyat dan kepercayaan sengaja diciptakan oleh penduduk setempat di masa yang lebih kemudian, setelah suatu kepurbakalaan tidak difungsikan lagi, oleh karenanya banyak yang dituturkan dalam bentuk legenda.

2. Cerita-cerita rakyat dan kepercayaan rakyat dikarang oleh masyarakat untuk mengurangi ketidakpahaman mereka terhadap suatu kepurbakalaan. Untuk mengurangi perasaan gentar karena dipandang angker, atau untuk membuat mereka akrab dengan suatu kepurbakalaan.

3. Dengan adanya cerita rakyat dan kepercayaan penduduk setempat terhadap suatu kepurbakalaan, maka dapat membantu keamanan kepurbakalaan itu dari para pelaku pencurian dan vandalisme. Penduduk setempat akan berupaya melindungi bukti peninggalan dari kisah rakyat yang telah akrab dikenalnya dan diwariskan dari generasi-generasi terdahulu. Dengan adanya kesadaran tersebut suatu kepurbakalaan relatif lebih terjaga, karena penduduk setempat memperhatikannya.

4. Kajian arkeologi agaknya perlu memperhatikan uraian cerita-cerita dan kepercayaan rakyat terhadap suatu monumen atau peninggalan kuno. Ada kemungkinan di dalam cerita-cerita dan kepercayaan rakyat tersebut terdapat petunjuk yang dapat digunakan untuk memecahkan perkara arkeologi yang berkaitan dengan situs dan kepurbakalaan yang dimaksudkan. Jadi tidak semua cerita rakyat tentang suatu kepurbakalaan bersifat ontologis, namun ada yang bersiaft historis, namun telah ditutupi dengan metafora yang lebih mudah untuk dipahami oleh penduduk lokal.

Kajian kisah-kisah dan kepercayaan rakyat di seputar kepurbakalaan dan peninggalan arkeologi di Indonesia masih belum dilakukan. Telaah singkat ini dapat dianggap hanya sebagai pengantar untuk mengarahkan jalan kepada kajian tersebut, mungkin di masa mendatang akan ada yang berminat melakukannya. Masih cukup banyak kepurbakalaan di Indonesia yang dilengkapi dengan kisah rakyat dan kepercayaannya sendiri. Misalnya pura-pura kuno di Bali yang senantiasa dihubungkan dengan Dang Hyang Nirartha, tokoh legenda pembaharu agama Hindu di Pulau Dewata dalam abad ke-15. 
Ada juga kisah rakyat yang mulai menghilang dan tidak dikenal lagi bahkan oleh penduduk setempat sekalipun, hal ini dapat terjadi karena rusaknya kepurbakalaan, atau berubahnya lingkungan alam di sekitar kepurbakalaan. Dalam hal ini maka kajian dokumentasi cerita rakyat menjadi penting sebelum menghilang tidak dapat diwariskan ke generasi berikutnya. Sebagai contoh adalah cerita tentang Candi Kendalisada (Kepurbakalaan LXV) di Gunung Penanggungan. Sampai tahun 1925-an, ketika pertama kali situs Gunung Penanggungan dieksplorasi, kisah tentang kerajaan Hanuman Kendalisada masih dikenal oleh penduduk lereng utara Penanggungan. Candi Kendalisada merupakan bekas istana dari Hanuman, terletak di tepi tebing curam dan berbentuk punden berundak-undak. Di puncak punden terdapat altar persajian yang bercungkup, mengesankan sebagai singgasana raja. Di lereng bawah tebing merupakan hutan lebat yang cukup rimbun, di sanalah ratusan kera hidup dan berkembang dengan leluasa, sehingga penduduk setempat percaya bahwa Candi Kendalisada dan sekitarnya adalah kerajaan kera dengan rajanya adalah Hanuman.

Akan tetapi dewasa ini keadaannya telah berbeda, hutan rimbun telah tiada, punden berundak di bagian puncaknya telah runtuh, relief-relief di dinding goa telah dicuri orang. Akibat hutan telah gundul, kera-kera pun tidak ada lagi yang hidup di sekitar Candi Kendalisada. Candi itu masih menyimpan nama Kendalisada sebagai kerajaan Hanuman, namun monyet-monyet yang merupakan balatentara Hanuman telah lama menghilang, anak-anak muda penduduk setempat sekarang tidak tahu lagi mengapa candi itu bernama Kendalisada. Sebelum kisah-kisah itu berangsur-angsur menghilang, maka kajian yang paling awal, yaitu dokumentasi dan inventarisasi kisah dan kepercayaan rakyat yang berhubungan dengan peninggalan arkeologi sudah sepantasnya segera dilakukan.

\section{PUSTAKA ACUAN}

Bernet Kempers, A. J. Ancient Indonesian Art. Amsterdam: CPJ.van der Peet. 1959. \& Soekmono. Candi Mendut, Pawon, dan Borobudur. Bandung:

Ganaco N.V. 1974.

Sukardja, Djadja H. Situs Karangkamulyan dan Kisah Ciung Wanara. Ciamis: Seksi Kebudayaan Kandepdikbud Kabupaten Ciamis. 1997.

Suleiman, Satyawati, 1981. Monumen-monumen Indonesia Purba. Jakarta: Pusat Penelitian Arkeologi Nasional.

Sutarto. Legenda Kasada dan Karo Orang Tengger Lumajang. Depok: Fakultas Sastra Universitas Indonesia. 1997.

Timoer, Soenarto. Thothokkerot: Cerita Rakyat Sebagai Sumber Penelitian Sejarah. Jakarta: P. N. Balai Pustaka. 1981.

Van Der Hoop, A. N. J. Th. A. Th. Megalithic Remains in South-Sumatra. Translated by William Shirlaw. Zutphen: W. J. Thieme \& Cie. 1932.

Van Peursen, C.A. Strategi Kebudayaan. Yogyakarta: Yayasan Kanisius. Jakarta: BPK. Gunung Mulia. 1976. 